\title{
Anatomical Response of Atriplex Leaves under Different Levels of Sodium Chloride Salinity
}

\author{
Mohammed Abdul Rahman Al-Muwayhi \\ Physics and Chemistry Dept., Fac. of Science, Shaqra Univ., P.O. Box 33, Shaqra, 11961, Kingdom of Saudi Arabia
}

Received: $14 / 10 / 2020$

\begin{abstract}
Salinity causes physiological, morphological, and anatomical modifications in Mediterranean saltbush Atriplex halimus and giant saltbush Atriplex nummularia. Both species, which belong to Chenopodiaceae, are true xerophyte as shown from Kranz-anatomy and salt storage trichromes. Response of both species to salinity were differed according to genetic structures. Atriplex species leaves characteristic by presence of salt accumulating cells on upper and lower leaf epidermis, which have ecological significance. Increasing of salinity had negative effect on anatomical measurements of $A$. halimus leaves. However, low level of salinity had positive effect in $A$. nummularia leaves, but high level of had negative effect on leaves.
\end{abstract}

Keywords: Atriplex halimus - Atriplex nummularia - salt stress - leaf anatomy

\section{INTRODUCTION}

Salinity is one of the most important topics in eco-agriculture system, which adversely affected more than $50 \%$ of crop production of the world. Salinity stress is more complicated in arid regions, caused functional, morphological, and anatomical modifications in plants (Marius-Nicușor Grigore and Toma, 2020; Keshavarzi, 2020). Atriplex is speciesrich genus of about 300 species belong to the Chenopodiaceae, the main distribution of the family lies in the Old World. Atriplex species are euhalophytes, annual or perennial herbs, sub shrubs or shrubs (Kühn et al., 1993). Mediterranean saltbush Atriplex halimus is an evergreen fodder shrub, while giant saltbush Atriplex nummularia is woody perennials. Both species are true xerophyte and cultivated as salt resistant forage in grazing systems (Norman et al., 2004). Atriplex is a halophyte with potential interest for saline soil reclamation and Phytoremediation (Benzarti et al., 2014). The anatomy of Atriplex genus leaves and the marked anatomical variations of it proved important from an ecological viewpoint (Black, 1954; Evert, 2006). Atriplex species leaves characteristic by presence of salt bladders, fused vesicles on upper and lower leaf epidermis, which have ecological significance. Genus Atriplex consider halophyte salt includer, particularly adapted to arid, semi-arid and salt-affected areas (de Araújo et al., 2006; de Villiers et al., 1996). The present paper describes, the leaf different anatomical structure related to salt tolerance of both species Atriplex halimus and $A$. nummularia, to monitor the anatomical response of Atriplex leaves under different levels of sodium chloride salinity.

\section{MATERIALS AND METHODS}

\section{Plant Material and Treatments:}

Seeds of both Atriplex nummularia and Atriplex halimus were cultivated under greenhouse conditions with thermos period $32: 17^{\circ} \mathrm{C}$ fluctuation (day and night) and irrigated as normal agricultural practices. Seedlings (After occurrence of the first five true leaves) transferred to $30 \mathrm{~cm}$ diameter plastic pots filled with sandy loam by ratio $1: 1$, moved out of the greenhouse, and exposed to salt-water irrigation treatments, continued for six months treated with saline water every month (4 times). Soil physical and chemical properties measured according to (Cassel and Nielsen, 1986; Rhoades and Oster, 1982) as shown in Table (1).

Table (1): Physical and chemical properties of the soil

\begin{tabular}{lcc}
\hline \multicolumn{1}{c}{ Measurements } & Soil \\
\hline $\mathbf{p H}$ & & 8.40 \\
$\mathbf{E C}(\mathbf{d S} / \mathbf{m})$ & 9.1 \\
Soluble & $\mathrm{Ca}^{2+}$ & 35.0 \\
Cations & $\mathrm{Mg}^{2+}$ & 19.5 \\
meq/L & $\mathbf{N a}^{+}$ & 34.3 \\
& $\mathbf{K}^{+}$ & 2.0 \\
Soluble & $\mathbf{C O}_{3}{ }^{-2}$ & 0.125 \\
Anions meq/L & $\mathbf{H C O}_{3}^{-}$ & 3.5 \\
& $\mathbf{C l}^{-}$ & 56.3 \\
& $\mathbf{S o}_{\mathbf{4}}{ }^{2-}$ & 21.9 \\
Saturation point \%o & 27.3 \\
Pot capacity (at 1 bar) & 13.6 \\
Wilting point (at 15 bars) & 6.8 \\
\hline
\end{tabular}

The plants irrigated regularly with sodium chloride solutions concentration as follows, $50 \mathrm{ppm}$ (T1) as control, $400 \mathrm{ppm}$ (T2), $800 \mathrm{ppm}$ (T3) and 1600 ppm (T4). The final concentration of $\mathrm{NaCl}$ in soil was 200, 4800, 9600 and 19200 ppm.

\section{Anatomical Structure:}

For studying the anatomical response of Atriplex leaves, killing and fixation of the leaves in 50\% F.A.A (formalin alcohol acetic acid) solution, dehydration and clearing in xylol and embedded in pure paraffin wax (melting point $56^{\circ} \mathrm{C}$ ) were carried out as described by (Das, 1971). Using a rotary microtome, transverse sections of the lamina $(10 \mu)$ were obtained and double stained with safranin and light green. To monitor the anatomical response of Atriplex leaves under different levels of sodium chloride salinity, the following characters were measured, average thickness of upper 
epidermis by micrometer $(\mu)$, average thickness of lower epidermis $(\mu)$, average thickness of the mesophyll $(\mu)$, average thickness of the midrib by millimeter ( $\mathrm{mm}$ ), average thickness (anticlinal diameter) of main vascular bundle MVB (mm), average width of MVB (mm), average thickness of xylem tissue per MVB $(\mu)$, average diameter of xylem vessels per MVB $(\mu)$ and average thickness of phloem tissue per MVB $(\mu)$.

Statistical analysis:

The data were subjected to One-way analysis of variance (ANOVA) one using CoStat Version 6.311 (CoHort soft- ware, Berkeley, CA 94701) according to (Steel, Torrie, \& Dickey, 1980) with probability $\leq 0.05$.

\section{RESULTS AND DISCUSSION}

The leaves of all treatments (control and different concentration of $\mathrm{NaCl}$ ) of Atriplex specimens of the two species, Atriplex halimus and $A$. nummularia, transverse sections showed the presence of Kranz-type (assimilated sheath) leaf anatomy as seen in Figure1. The vascular surrounded by two layers of bundle-sheath cells, rich in chloroplasts, with bundle sheath cells seems densely stained (Fig. 1a). (Frankton and Bassett, 1970; Jacobs, 2001; Troughton and Card,
1974) reported that C4 plants had Kranz cells or bundle sheath such as Atriplex halimus and A. nummularia. All transverse sections of Atriplex specimens' lamina characteristic by presence of a firmly fused vesicular tissue as vesicles on both upper and lower epidermis. Those salt bladders had ecological significance such as; a heat insulator and reflector prevent excessive transpiration, a water-storage tissue and a medium to absorb atmospheric moisture into the mesophyll of the leaf. Such adaptation is worth under desert condition where intense solar heat and extreme drought (Black, 1954). Also, (Freitas and Breckle, 1992; Mozafar and Goodin, 1970; Osmond et al., 2012; Yuan et al., 2016) suggested that bladders accumulate $\mathrm{Na}^{+}$and $\mathrm{Cl}^{-}$ions, and these bladders are associated with the Atriplex species tolerance to salinity.

Table (2) and Figure (1) summarizes the anatomical response of Atriplex as affected by different salinity concentrations compared to normal level of $\mathrm{NaCl}$ (such as halophytes). Upper and lower epidermis thickness $(\mu)$ of $A$. halimus significantly decrease with the increasing of salinity from $15.64 \mu$ in control to $8.99 \mu$ in T4, whereas, the same thickness of $A$. nummularia vary with increasing salinity as shown in (Table 2).

Table (2): Effect of $\mathrm{NaCl}$ levels on Atriplex lamina anatomy in transverse sections of Atriplex halimus and A. nummularia under T1, T2, T3 and T4 treatments respectively

\begin{tabular}{|c|c|c|c|c|c|}
\hline \multicolumn{6}{|c|}{ Atriplex halimus L. } \\
\hline \multicolumn{6}{|c|}{ Treatments } \\
\hline Variables & $\mathbf{T 1}$ & $\mathbf{T 2}$ & T3 & T4 & $\begin{array}{l}\text { L.S.D } \\
\leq \mathbf{0 . 0 5}\end{array}$ \\
\hline Average thickness of upper epidermis $(\mu)$ & $15.64^{\mathrm{a}}$ & $9.64^{b}$ & $9.21^{\mathrm{b}}$ & $8.99^{b}$ & 5.23 \\
\hline Average thickness of lower epidermis $(\mu)$ & $10.47^{\mathrm{a}}$ & $9.27^{\mathrm{ab}}$ & $6.91^{\mathrm{ab}}$ & $6.39^{\mathrm{b}}$ & 3.98 \\
\hline Average thickness of the mesophyll $(\mu)$ & $161.48^{\mathrm{a}}$ & $137.95^{\mathrm{b}}$ & $88.75^{\mathrm{c}}$ & $145.42^{b}$ & 13.14 \\
\hline Average thickness of the midrib (mm) & $0.421^{\mathrm{c}}$ & $0.500^{\mathrm{a}}$ & $0.460^{\mathrm{b}}$ & $0.440^{\mathrm{bc}}$ & 0.029 \\
\hline $\begin{array}{l}\text { Average thickness (anticlinal diameter) } \\
\text { of MVB (mm) }\end{array}$ & $0.169^{\mathrm{c}}$ & $0.239^{\mathrm{a}}$ & $0.207^{\mathrm{b}}$ & $0.198^{\mathrm{b}}$ & 0.018 \\
\hline Average width of MVB (mm) & $0.175^{\mathrm{c}}$ & $0.263^{\mathrm{a}}$ & $0.194^{\mathrm{c}}$ & $0.225^{\mathrm{b}}$ & 0.021 \\
\hline $\begin{array}{l}\text { Average thickness of xylem tissue per } \\
\text { MVB }(\mu)\end{array}$ & $75.28^{\mathrm{ab}}$ & $86.48^{\mathrm{a}}$ & $68.91^{\mathrm{ab}}$ & $56.41^{\mathrm{b}}$ & 24.88 \\
\hline $\begin{array}{l}\text { Average diameter of xylem vessels per } \\
\operatorname{MVB}(\mu)\end{array}$ & $12.77^{\mathrm{a}}$ & $6.92^{\mathrm{b}}$ & $9.09^{\mathrm{b}}$ & $8.26^{\mathrm{b}}$ & 3.17 \\
\hline $\begin{array}{l}\text { Average thickness of phloem tissue per } \\
\text { MVB }(\mu)\end{array}$ & $45.67^{\mathrm{b}}$ & $64.42^{\mathrm{a}}$ & $39.79^{\mathrm{b}}$ & $57.48^{\mathrm{a}}$ & 10.19 \\
\hline \multicolumn{6}{|c|}{ Atriplex nummularia Lindl. } \\
\hline Average thickness of upper epidermis $(\mu)$ & $11.224^{\mathrm{bc}}$ & $13.720^{\mathrm{ab}}$ & $15.322^{\mathrm{a}}$ & $8.957^{\mathrm{c}}$ & 2.92 \\
\hline Average thickness of lower epidermis $(\mu)$ & $8.758^{\mathrm{c}}$ & $12.342^{\mathrm{b}}$ & $15.566^{\mathrm{a}}$ & $9.312^{\mathrm{c}}$ & 2.299 \\
\hline Average thickness of the mesophyll $(\mu)$ & $165.147^{\mathrm{b}}$ & $203.251^{\mathrm{a}}$ & $169.282^{\mathrm{b}}$ & $162.048^{\mathrm{b}}$ & 16.53 \\
\hline Average thickness of the midrib (mm) & $0.280^{\mathrm{c}}$ & $0.465^{\mathrm{a}}$ & $0.398^{\mathrm{b}}$ & $0.440^{\mathrm{a}}$ & 0.030 \\
\hline $\begin{array}{l}\text { Average thickness (anticlinal diameter) } \\
\text { of MVB (mm) }\end{array}$ & $0.137^{\mathrm{c}}$ & $0.215^{\mathrm{a}}$ & $0.195^{\mathrm{b}}$ & $0.188^{\mathrm{b}}$ & 0.012 \\
\hline Average width of MVB (mm) & $0.106^{\mathrm{c}}$ & $0.202^{\mathrm{a}}$ & $0.176^{\mathrm{b}}$ & $0.166^{\mathrm{b}}$ & 0.016 \\
\hline $\begin{array}{l}\text { Average thickness of xylem tissue per } \\
\text { MVB }(\mu)\end{array}$ & $56.171^{b}$ & $83.129^{\mathrm{a}}$ & $63.297^{\mathrm{b}}$ & $57.396^{\mathrm{b}}$ & 13.77 \\
\hline $\begin{array}{l}\text { Average diameter of xylem vessels per } \\
\operatorname{MVB}(\mu)\end{array}$ & $5.818^{\mathrm{c}}$ & $10.873^{\mathrm{a}}$ & $10.956^{\mathrm{a}}$ & $8.127^{\mathrm{b}}$ & 1.66 \\
\hline $\begin{array}{l}\text { Average thickness of phloem tissue per } \\
\text { MVB }(\mu)\end{array}$ & $31.692^{b}$ & $49.257^{\mathrm{a}}$ & $39.229^{\mathrm{ab}}$ & $43.196^{\mathrm{a}}$ & 10.68 \\
\hline
\end{tabular}



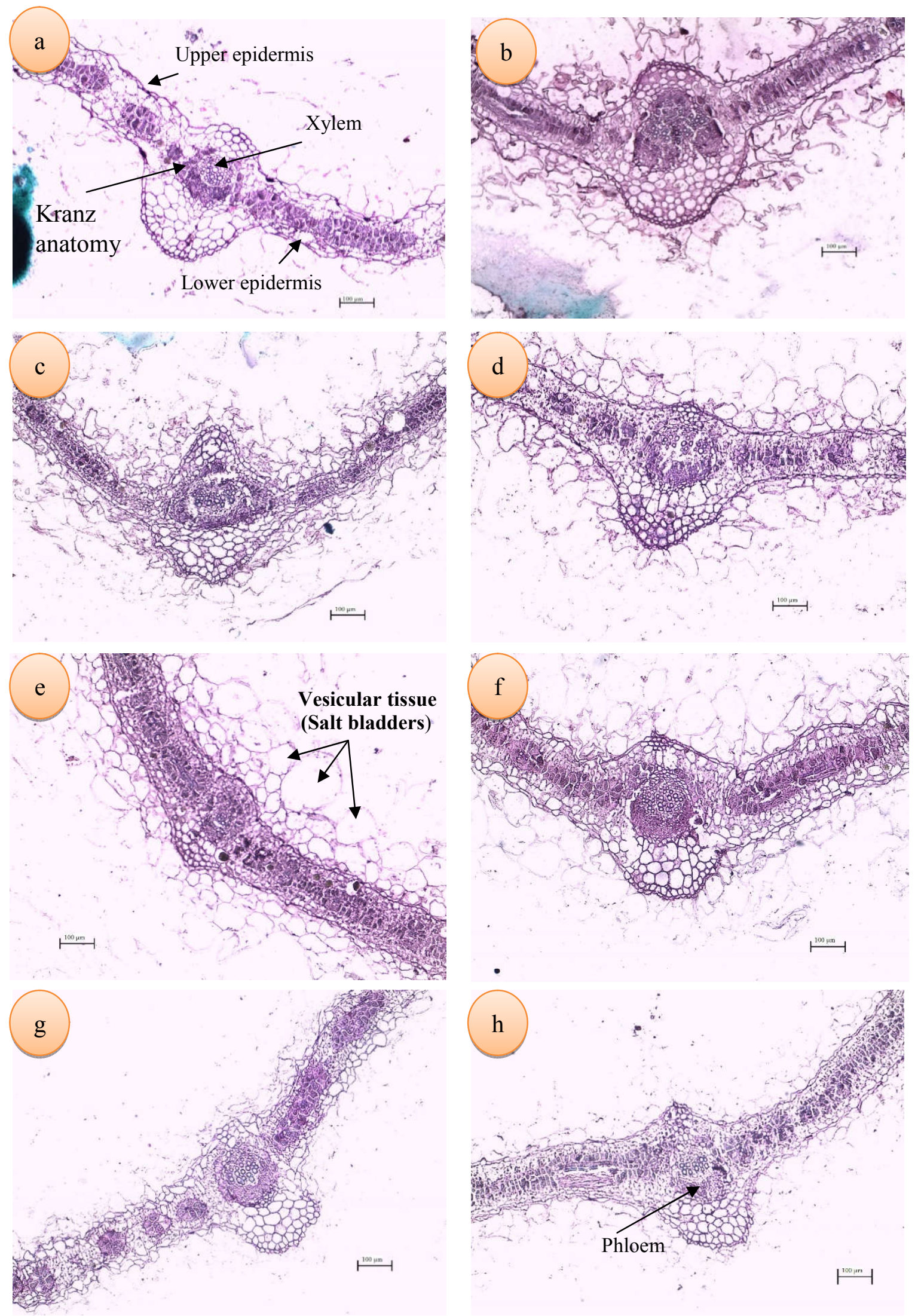

Figure (1): Transverse sections of the lamina of Atriplex (a-b) Atriplex halimus and (e-g) Atriplex nummularia under $\mathrm{T} 1, \mathrm{~T} 2, \mathrm{~T} 3$ and $\mathrm{T} 4$ respectively 
In addition, the average thickness of the mesophyll decreased significantly under high level of salinity from $161.48 \mu$ in control to $88.75 \mu$ in T3, on contrast $A$. nummularia average thickness of the mesophyll increased from $165.147 \mu$ in control (T1) to $203.251 \mu$ in T2 and this is normal because of $A$. nummularia is euhalophyte (de Souza et al., 2012).

Average thickness of the midrib (mm), average thickness (anticlinal diameter) of main vascular bundle (mm) and average width of MVB (mm) were not significantly different among all treatments. Average thickness of xylem tissue per $\operatorname{MVB}(\mu)$, average diameter of xylem vessels per MVB $(\mu)$ were highly indicated-character for salinity in A. halimus as shown in Table (2) and Fig. (1); but vice versa as shown in $A$. nummularia. Average thickness of phloem tissue per MVB was vary among treatments from $45.67 \mu$ in control (T1) of A. halimus to $57.48 \mu$ in T4; whereas, in A. nummularia were $31.69 \mu$ in $\mathrm{T} 1$ and $43.19 \mu$ in $\mathrm{T} 4$. These findings indicated that salt accumulation from $400 \mathrm{ppm}$ to $19200 \mathrm{ppm} \mathrm{NaCl}(0.30$ to $30 \mathrm{dS} / \mathrm{m})$, respectively, had negative effect on growth and anatomical, even in halophytes as shown at structure of A. halimus lamina. However, increasing salinity levels had positive effect in $A$. nummularia. It mean that salinity treatment of species significantly different according to genetic structure. These findings agreed with, (Benzarti et al., 2014; Boughalleb et al., 2009; Marius-Nicusor Grigore et al., 2014; Marius-Nicușor Grigore and Toma, 2017; Kelley et al., 1982; Martìnez et al., 2004; Ounaissia et al., 2019; Troughton and Card, 1974; Walker et al., 2014).

\section{CONCLUSION}

Results of the present study indicate that, anatomical characters of lamina were differed between two species of Atriplex under salinity stress. Halophytes such as Atriplex showed same trend of response to high level of salinity as glycophytes.

\section{REFERENCES}

Benzarti, M., K. B. Rejeb, D. Messedi, A. B. Mna, K. Hessini, M. Ksontini, ...... A. Debez (2014). Effect of high salinity on Atriplex portulacoides: Growth, leaf water relations and solute accumulation in relation with osmotic adjustment. South African Journal of Botany, 95: 70-77.

Black, R. (1954). The leaf anatomy of Australian members of the genus Atriplex. I. Atriplex vesicaria Heward and $A$. nummularia Lindl. Australian Journal of Botany, 2(3): 269-286.

Boughalleb, F., M. Denden and B. B. Tiba (2009). Anatomical changes induced by increasing $\mathrm{NaCl}$ salinity in three fodder shrubs, Nitraria retusa, Atriplex halimus and Medicago arborea. Acta Physiologiae Plantarum, 31(5): 947-960.

Cassel, D. and D. Nielsen (1986). Field capacity and available water capacity. Methods of Soil
Analysis: Part 1 Physical and Mineralogical Methods, 5: 901-926.

Das, N. (1971). University of Illinois at Chicago Circle Ruth L. Willey, Microtechniques, A Laboratory Guide, The Macmillan Company, p. 99: Pergamon.

de Araújo, S. A., J. A. Silveira, T. D. Almeida, I. Rocha, D. L. Morais and R. A. Viégas (2006). Salinity tolerance of halophyte Atriplex nummularia L. grown under increasing $\mathrm{NaCl}$ levels. Revista Brasileira de Engenharia Agrícola e Ambiental, 10(4): 848-854.

de Souza, E. R., M. B. G. dos Santos Freire, K. P. V., da Cunha, C. W. A. do Nascimento, H. A. Ruiz and C. M. Teixeira Lins (2012). Biomass, anatomical changes and osmotic potential in Atriplex nummularia Lindl. cultivated in sodic saline soil under water stress. Environmental and Experimental Botany, 82, 20-27. doi:https://doi.org/10.1016/j.envexpbot.2012.03.007

de Villiers, A. J., I. von Teichman, M. W. van Rooyen and G. K. Theron (1996). Salinity-induced changes in anatomy, stomatal counts and photosynthetic rate of Atriplex semibaccata R. Br. South African Journal of Botany, 62(5): 270-276. doi:https://doi.org/10.1016/S02546299(15)30656-6

Evert, R. F. (2006). Esau's plant anatomy: meristems, cells, and tissues of the plant body: their structure, function, and development: John Wiley \& Sons.

Frankton, C. and I. Bassett (1970). The genus Atriplex (Chenopodiaceae) in Canada. II. Four native western annuals: A. argentea, A. truncata, A. powellii, and A. dioica. Canadian Journal of Botany, 48(5): 981-989.

Freitas, H. and S. W. Breckle (1992). Importance of Bladder Hairs for Salt Tolerance of FieldGrown Atriplex Species from a Portuguese Salt Marsh. Flora, 187: 283-297. doi:https://doi.org/10.1016/S0367-2530(17)32233-8

Grigore, M.-N., L. Ivanescu and C. Toma (2014). Halophytes: an integrative anatomical study: Springer.

Grigore, M.-N. and C. Toma (2017). Anatomical adaptations of halophytes. A review of classic literature and recent findings. Cham: Springer.

Grigore, M. -N. and C. Toma (2020). Integrative Anatomy of Halophytes from Mediterranean Climate. Handbook of Halophytes: From Molecules to Ecosystems towards Biosaline Agriculture, 1-35.

Jacobs, S. (2001). Review of leaf anatomy and ultrastructure in the Chenopodiaceae (Caryophyllales). Journal of the Torrey Botanical Society, 236-253.

Kelley, D. B., J. Goodin and D. R. Miller (1982). Biology of Atriplex Contributions to the Ecology of Halophytes (pp. 79-107): Springer.

Keshavarzi, M. (2020). An Overview of Ecological Anatomy of Poaceae Halophytes from Iran. 
Handbook of Halophytes: From Molecules to Ecosystems towards Biosaline Agriculture, 129.

Kühn, U., V. Bittrich, R. Carolin, H. Freitag, I. Hedge, P. Uotila and P. Wilson (1993). Chenopodiaceae Flowering Plants Dicotyledons (pp. 253-281): Springer.

Martinez, J.-P., S. Lutts, A. Schanck, M. Bajji and J.M. Kinet (2004). Is osmotic adjustment required for water stress resistance in the Mediterranean shrub Atriplex halimus L? Journal of Plant Physiology, 161(9): 10411051.doi:https://doi.org/10.1016/j.jplph.2003.12 .009

Mozafar, A. and J. Goodin (1970). Vesiculated hairs: a mechanism for salt tolerance in Atriplex halimus L. Plant Physiology, 45(1): 62-65.

Norman, H. C., C. Freind, D. G. Masters, A. J., Rintoul, R. A. Dynes and I. H. Williams (2004). Variation within and between two saltbush species in plant composition and subsequent selection by sheep. Australian Journal of Agricultural Research, 55(9): 9991007.

Osmond, C. B., O. Björkman and D. J. Anderson (2012). Physiological processes in plant ecology: toward a synthesis with Atriplex
(Vol. 36): Springer Science \& Business Media.

Ounaissia, K., F. Medecine, L. Ailane, H. Laredj, S. Bennadja and D. Smati (2019). Anatomical Study of Atriplex halimus L. (Guettaf) Growing under the Climatic Conditions of Biskra - Algeria.

Rhoades, J. and J. Oster (1982). Methods of soil analysis, Part 2. American Society of Agronomy.

Steel, R., J. Torrie and D. Dickey (1980). Principles and procedures of statistics. McGraw-Hill, New York. Principles and procedures of statistics. $2^{\text {nd }}$ ed. McGraw-Hill, New York.

Troughton, J. H. and K. Card (1974). Leaf anatomy of Atriplex buchananii. New Zealand journal of botany, 12(2): 167-177.

Walker, D., S. Lutts, M. Sánchez-García and E. Correal (2014). Atriplex halimus L.: Its biology and uses. Journal of Arid Environments, 100: 111-121.

Yuan, F., B. Leng and B. Wang (2016). Progress in Studying Salt Secretion from the Salt Glands in Recretohalophytes: How Do Plants Secrete Salt? Frontiers in Plant Science, 7(977). doi:10.3389/fpls.2016.00977.

\section{الاستجابة التشريحية في أوراق نبات القطف Atriplex تحت مستويات مختلفة من ملوحة كلوريد الصوديوم

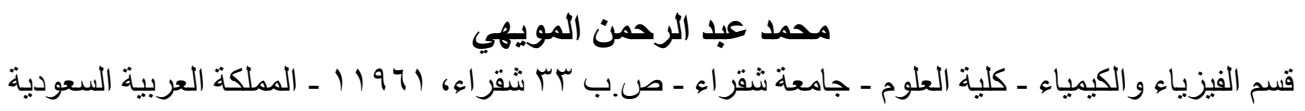

تسبب الملوحة تغييرات فسيولوجية ومورفولوجية ونتشريحية في نبات القطف Atriplex بنوعيه Atriplex halimus و Atriplex nummularia

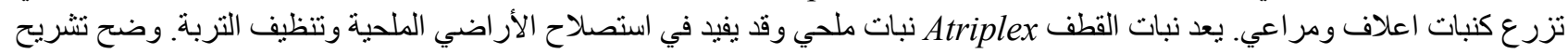

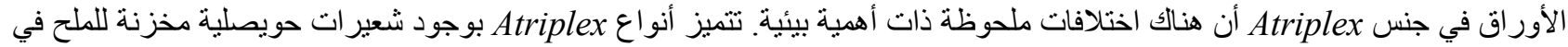

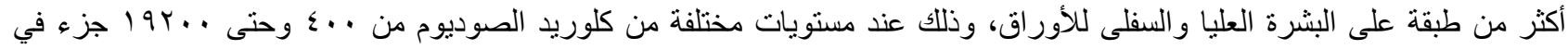

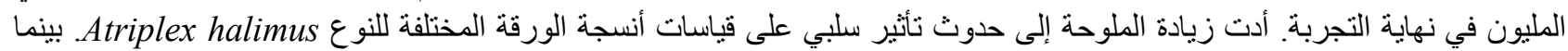

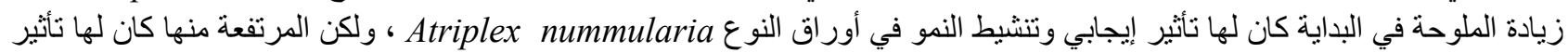

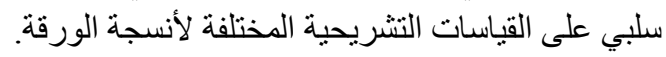

